\title{
Relative importance of different size food particles in the natural diet of oyster larvae (Crassostrea virginica)
}

\author{
Brad S. Baldwin ${ }^{*}$ Roger I. E. Newell ${ }^{* *}$ \\ Horn Point Environmental Laboratory, Center for Environmental and Estuarine Studies, University of Maryland System, \\ PO Box 775, Cambridge, Maryland 21613, USA
}

\begin{abstract}
We examined the feeding activity of planktotrophic larvae of the eastern oyster Crassostrea virginica on different size particles suspended in surface waters of 2 subestuaries of Chesapeake Bay, USA. Particle suspensions were characterized using particle counters and microscopic observations. At both sites, particle assemblages were dominated (in terms of particle number and volume) by particles (predominantly plankton cells) with equivalent spherical diameters $<5 \mu \mathrm{m}$. Feeding experiments demonstrated that small $(<150 \mu \mathrm{m}$ shell length) and large (>200 $\mu \mathrm{m})$ oyster larvae typically ingested particles between 0.5 and $12 \mu \mathrm{m}$. However, in the presence of blooms of large 110 to $30 \mathrm{\mu m}$ ) dinoflagellates, small and large larvae extended their maximum ingested particle size to about 16 and $30 \mu \mathrm{m}$, respectively. These results indıcate that oyster larvae generally exploit foods within the characteristic particle biomass peak present in these estuaries and opportunistically feed upon periodic blooms of large plankton cells. Larvae derived a large percentage (range 20 to $90 \%$ ) of the total ingested particle volume from picoplankton-size (here defined as 0.5 to $3 \mu \mathrm{m}$ ) particles. These small particles constituted a larger percentage of the material ingested by small larvae than that ingested by large larvae. By comparison, both sizes of larvae derived about 2 to $40 \%$ and about 5 to $20 \%$ of total ingested food volume from 3 to $5 \mu \mathrm{m}$ and 5 to $10 \mu \mathrm{m}$ particles, respectively. In experiments with abundant dinoflagellates $>10 \mu \mathrm{m}$ in size, both sizes of larvae derived 20 to $30 \%$ of their total ingested volume from these particles.
\end{abstract}

KEY WORDS: Bivalve larvae $\cdot$ Feeding $\cdot$ Plankton

\section{INTRODUCTION}

Planktotrophic larvae are produced by many benthic marine invertebrates (Thorson 1950, Mileikovsky 1971, Strathmann 1987) and yet little is understood about the feeding habits or nutritional state of natural larval populations. Greater knowledge of these aspects of larval biology can improve our understanding of factors influencing larval dispersal, supply, and recruitment, as well as the trophic role these larvae play in pelagic food webs.

- Present address: Institute of Marine and Coastal Sciences Mar. Coast. Sci. Bldg, Cook Campus, Rutgers University, New Brunswick, New Jersey 08903-0231, USA

-Addressee for reprint requests
In an earlier study (Baldwin \& Newell 1991), we sought to define the types of natural food particles used by planktotrophic larvae of the oyster Crassostrea virginica, an important member of benthic communities along the eastern and southern coasts of the USA. In that study our primary goal was to elucidate the trophic groups of planktonic food organisms that are ingested by these larvae. Here we assess the relative importance of different sizes of suspended particles in the natural diet of these larvae.

Previous laboratory studies have shown that bivalve larvae generally grow and survive best when fed relatively small (about 3 to $5 \mu \mathrm{m}$ ) cultured cells (reviewed by Webb \& Chu 1982, Bayne 1983, Strathmann 1987). In part, this is because bivalve larvae are most efficient at removing cells of this size from suspension (Walne 
1965, Riisgărd et al. 1980, Sprung 1984, Riisgård 1988). However, in nature, where the food particle assemblages available to larvae are much more complex and variable in composition, the relative importance of different size particles to larval nutrition is unclear. If larvae can ingest plankton cells outside the 3 to $5 \mu \mathrm{m}$ size range, even at low efficiencies, then they may derive significant nutritional benefit from picoplankton (defined here as cells 0.5 to $3 \mu \mathrm{m}$ ), which are numerically abundant, and from the less abundant $>5 \mu \mathrm{m}$ cells, which have large cellular volume and biomass

Recent work indicates that bivalve larvae can readily ingest very small cells ( $\leq 1 \mu \mathrm{m})$ that may be nutritionally important in their diet (Gallager 1988, Baldwin \& Newell 1991, Chalermwat 1992, Douillet 1993a, b, Douillet \& Langdon 1993, Gallager et al. 1994). Larvae of Crassostrea virginica can also ingest large cells up to about 30 um (Guillard 1958, Mackie 1969, Baldwin \& Newell 1991). Thus, given the abundance of picoplankton in Chesapeake Bay (Ray et al. 1989, Malone \& Ducklow 1990, Baldwin \& Newell 1991, Affronti \& Marshall 1993) and the ability of oyster larvae to ingest large cells such as dinoflagellates that commonly bloom in the bay (Van Valkenburg \& Flemer 1974, Seliger et al. 1982, Sellner \& Kachur 1987, Baldwin \& Newell 1991, Gallegos 1992), we hypothesized that oyster larvae could derive a significant portion of their diet from particles $<3$ and $>5 \mu \mathrm{m}$. As a test we characterized: (1) the size, abundance, and variability of suspended food particle assemblages in parts of Chesapeake Bay, and (2) the sizes and amounts of this food material ingested by $C$. virginica larvae.

\section{MATERIALS AND METHODS}

Characterization of suspended particle assemblages. Natural particle assemblages were collected on different dates from both the Choptank River and Little Choptank River subestuaries of Chesapeake Bay (Table 1). Both sites support oyster populations and samples of particle suspensions were collected during summer months when oyster larvae are expected to be present in the water column (Kennedy 1986). Samples were collected in buckets from surface waters $(<1 \mathrm{~m})$ at fixed sites that were about 4 and $2 \mathrm{~m}$ deep in the Choptank $\left(38^{\circ} 35^{\prime} \mathrm{N}, 76^{\circ} 7^{\prime} \mathrm{W}\right)$ and Little Choptank $\left(38^{\circ} 34^{\prime} \mathrm{N}\right.$, $76^{\circ} 10^{\prime} \mathrm{W}$ ) Rivers, respectively. Ambient temperature and salinity were measured and samples were then transported to the laboratory where they were processed under dim room light $\left(25 \mu \mathrm{E} \mathrm{m}^{-2} \mathrm{~s}^{-1}\right)$ at $25^{\circ} \mathrm{C}$.

Prior to use in feeding experiments, particle assemblage samples were filtered through a $30 \mu \mathrm{m}$ Nitex screen using reverse flow gravity filtration. This was done to remove metazoan grazers and to provide
Table 1. Particle assemblages and larval sizes used in feeding experiments with Crassostrea virginica. Natural assemblages collected from the Choptank (CR) and Little Choptank (LCR) Rivers. Expts 1 to 14 conducted from August 2 to 16, 1991 . Expts 15 and 16 on June 6, 1992. Water temperature ranged from 24 to $26^{\circ} \mathrm{C}$, salinity from 10 to $11 \mathrm{ppt}$. Expts 5 to 14 conducted with different dilutions (percentage dilution with filtered river water) of ambient suspensions. Expt 16 conducted with LCR and added dinoflagellates Glenodinium sp.

(G). Thirty larvae were measured for each experiment

\begin{tabular}{|ccc|}
\hline Expt & Particle assemblage & $\begin{array}{c}\text { Mean larval size } \\
(\mu \mathrm{m} \pm 1 . \mathrm{SD})\end{array}$ \\
\hline 1 & CR & $124.2 \pm 12.8$ \\
2 & CR & $260.1 \pm 18.0$ \\
3 & CR & $106.7 \pm 12.7$ \\
4 & CR & $278.4 \pm 14.3$ \\
5 & CR 0\% & $203.3 \pm 16.2$ \\
6 & CR 50\% & $203.3 \pm 16.2$ \\
7 & CR $80 \%$ & $203.3 \pm 16.2$ \\
8 & CR 90\% & $203.3 \pm 16.2$ \\
9 & CR 95\% & $203.3 \pm 16.2$ \\
10 & LCR 0\% & $203.3 \pm 16.2$ \\
11 & LCR 50\% & $203.3 \pm 16.2$ \\
12 & LCR 80\% & $203.3 \pm 16.2$ \\
13 & LCR 90\% & $203.3 \pm 16.2$ \\
14 & LCR 95\% & $203.3 \pm 16.2$ \\
15 & LCR & $220.5 \pm 13.2$ \\
16 & LCR + G & $220.5 \pm 13.2$ \\
\hline
\end{tabular}

larvae with an appropriate food particle size spectrum as determined in previous feeding experiments (Baldwin \& Newell 1991). Screened samples were used in feeding experiments (within $2 \mathrm{~h}$ of collection) or for larval preconditioning purposes (see below).

In Expts 5 to 14 we reduced ambient particle concentrations by dilution with filtered $(0.2 \mu \mathrm{m})$ river water (FRW). In Expt 16 we added the cultured dinoflagellate Glenodinium sp. (19 $\mu \mathrm{m}$ diameter) to a natural sample taken from the Little Choptank River in order to enhance the abundance of large cells. This alga was cultured on $\mathrm{f} / 2$ medium (Guillard 1975 ) at $25^{\circ} \mathrm{C}$ under constant illumination at $200 \mu \mathrm{E}$ $\mathrm{m}^{-2} \mathrm{~s}^{-1}$ and was harvested in stationary growth phase.

The size structure and particle concentrations of screened suspensions were characterized using particle counters and, in one case, microscopic observation. To simultaneously count a wide variety of potential food particles, suspensions were counted using a Coulter Multisizer II fitted with a $50 \mu \mathrm{m}$ orifice tube The particle size range counted by the Multisizer spanned 1 to $32 \mu \mathrm{m}$ and is based on the equivalent spherical diameter of particles. Particle abundance is expressed in terms of numbers or volume per $\mathrm{ml}$ of water. Sample counts were corrected for coincidence, which was generally 5 to $10 \%$; when this level was exceeded samples were diluted with FRW. 
Certain suspensions were also counted on a Coulter EPICS Profile II flow cytometer. The fluorescence (emission of $>630 \mathrm{~nm}$ light) and size (length) of particles between 0.5 and $20 \mu \mathrm{m}$ (plankton cells containing chorophyll) were quantified simultaneously using a $488 \mathrm{~nm}$ argon laser powered at $30 \mathrm{~mW}$. The concentrations and sizes of these natural particles were determined by including with each sample an internal standard consisting of fluorescent ( $<630 \mathrm{~nm}$ emission) microspheres (Coulter Corp., Polysciences, Inc.) of known concentration and size.

We also determined the floristic composition of the natural suspension used in Expts 3 and 4 using epifluorescence microscopy (see Table 2). Cells were sized, stained, and enumerated following previously reported procedures (Baldwin \& Newell 1991). In the present study, cells were stained with DAPI (Porter \& Feig 1980).

Duplicate samples from suspensions used in Expts 5 and 10 were collected on GF/F filters (nominal pore size ca $0.7 \mu \mathrm{m}$ ) for analysis of chlorophyll a (chl a) concentrations (Lorenzen 1966). Samples were taken from $30 \mu \mathrm{m}$ and $20 \mu \mathrm{m}$ screened (Nitex) suspensions and from suspensions that had been filtered through $10 \mu \mathrm{m}$ and $3 \mu \mathrm{m}$ Nuclepore filters. Concentrations of chl a were calculated by difference for the 3 to 10,10 to 20 , and 20 to $30 \mu \mathrm{m}$ size fractions.

Feeding experiments. To determine the sizes of particles ingested by Crassostrea virginica larvae, we conducted feeding experiments with small $(<150 \mu \mathrm{m}$ shell length) and large (>200 $\mu \mathrm{m}$ ) larvae (Table 1). Larval size was measured microscopically after feeding experiments were completed. Oyster larvae were obtained from the Horn Point Environmental Laboratory hatchery and were preconditioned to experimental conditions in the laboratory for $2 \mathrm{~d}$. Larvae were held at $25^{\circ} \mathrm{C}$ in the dark in $1 \mathrm{l}$ jars ( 1 to 5 larvae $\mathrm{ml}^{-1}$ ) containing particle suspensions collected and screened each day. This food material was replaced about every $12 \mathrm{~h}$. Larvae were placed into freshly collected and screened samples $2 \mathrm{~h}$ before, and at the onset of, actual feeding experiments.

Immediately before use in feeding experiments, preconditioned larvae were rinsed over $45 \mu \mathrm{m}$ Nitex screens with FRW in order to remove previously produced fecal material. Larvae were then placed in a petri dish containing the test particle suspension and viewed under a dissection microscope. Actively swimming individuals were pipetted from this dish and placed into $40 \mathrm{ml}$ glass jars containing the test suspension. Final concentrations of larvae were $1 \mathrm{ml}^{-1}$ for large larvae and $5 \mathrm{ml}^{-1}$ for small larvae. The jars were capped leaving no air bubbles and were placed on a plankton wheel $(1 \mathrm{rpm})$ held in a $25^{\circ} \mathrm{C}$, dark room for 8 to $10 \mathrm{~h}$. We conducted experiments in capped bottles to minimize loss of delicate microrganisms that may lyse as a consequence of aeration (D. Stoecker, Univ. Maryland, pers. comm.). Control jars containing the same suspension without larvae were prepared and incubated in identical fashion. Five replicate jars were established for each treatment.

After incubations, the contents of all jars were gently filtered through $45 \mu \mathrm{m}$ Nitex screens to separate larvae from test suspensions. Preliminary tests confirmed that this screening process had negligible effects on the concentration or size frequency distributions of the test suspensions. Collected suspensions were then analyzed on the Multisizer and, in some cases, the flow cytometer.

Another set of controls was run to correct for fecal production. In preliminary experiments we found that larvae produce fecal particles (confirmed using microscopic observation) about 2 to $15 \mu \mathrm{m}$ as measured by the Multisizer. These particles were not counted on the flow cytometer because their weak autofluorescence (confirmed using epifluorescence microscopy) was below the selected detection threshold of the instrument. To control for fecal production in experiments using the Multisizer, we transferred a portion of the preconditioned (i.e. prefed) larvae to FRW and incubated these jars as well as jars containing FRW alone for $1 \mathrm{~h}$, which, based on a gut evacuation rate of 4 times $\mathrm{h}^{-1}$ (Baldwin 1992), is sufficient time for larvae to void their guts in FRW. Resultant particle size frequency distributions of FRW jars were subtracted from those of the gut evacuation jars (negative values were set to zero) to establish the net particle production of larvae. We assumed that larvae incubated in experimental jars containing natural food suspensions would produce this amount and size distribution of feces every $15 \mathrm{~min}$. Therefore, to estimate a probable total amount of fecal material produced over the entire incubation period by larvae feeding in the experimental jars, we multiplied the net amount estimated via fecal controls by 4 (for an hourly production rate) and then by the number of hours experimental jars were incubated. These fecal counts were then subtracted from those for experimental jars to minimize underestimation of grazing.

Before calculation of feeding rates we used ANOVA and Student-Newman-Keuls (SNK) multiple range tests $\left(\alpha_{\mathrm{e}}=0.05\right)$ to test for significant differences between particle counts of suspensions from control (no larvae) and larval (corrected for fecal production) treatments. All statistical analyses were conducted using SAS (1985) software. This procedure not only assessed a grazer effect, it also established the size range of particles removed by the larvae. Larval feeding rates were then estimated for both the maximal size range ingested (e.g. 1 to $12 \mu \mathrm{m}$ ) and for various smaller size fractions within this range (e.g. 1 to $3 \mu \mathrm{m}$ ) using the equations of Marin et al. (1986): 


$$
\begin{aligned}
& k=\ln C_{t}-\ln C_{0} / t \\
& G_{0}=\left[k\left(C_{t}-C_{0} e^{k t}\right) /\left(1-\mathrm{e}^{k t}\right)\right]\left(1 / C_{0}\right) \\
& C R=V G_{0} / \mathrm{N} \\
& I R=C R C_{0}
\end{aligned}
$$

where $k$ is a coefficient for growth of particles $\left(\mathrm{h}^{-1}\right)$, $C_{l}$ is particle concentration (particles $\mathrm{ml}^{-1}$ ) at time $t$, $C_{0}$ is particle concentration (particles $\mathrm{ml}^{-1}$ ) at time 0 , $t$ is time (h), $G_{0}$ is grazing coefficient $\left(\mathrm{h}^{-1}\right)$ at initial particle concentration, $C R$ is clearance rate ( $\mathrm{ml}$ individual $\left.{ }^{-1} \mathrm{~h}^{-1}\right), V$ is the volume of the jar $(\mathrm{ml}), \mathrm{N}$ is the number of larvae in a jar, and $I R$ is ingestion rate (particles larva ${ }^{-1} \mathrm{~h}^{-1}$ ). Absolute values of feeding rates are reported in Baldwin \& Newell (1995); here we report the range of particle sizes ingested and the proportion of total ingested food derived from various size fractions.

\section{RESULTS}

\section{Size structure of natural suspensions}

The natural particle assemblages sampled in this study represent a wide variety of size frequency distributions potentially encountered by larvae in nature
(Fig. 1). This is particularly evident in distributions of particle volume. A general feature of each sample is the large overall volume peak $<5 \mu \mathrm{m}$. The sample taken from the Little Choptank River on August 16 , 1991 (Fig. 1D) had a similar size distribution but a much larger amount of suspended material than samples taken from the Choptank River (Fig. 1A to C). Above $5 \mu \mathrm{m}$, the volume of suspended material is normally quite low, but on August 7, 1991 (Fig. 1B) there was a large amount of $>5 \mu \mathrm{m}$ particle volume. Concentrations of these larger particles were unusually high and in $>10 \mu \mathrm{m}$ fractions, phytoplankton was dominated by large dinoflagellates (Table 2). Dinoflagellate counts were within the range of values reported in other studies documenting summer blooms of large dinoflagellates in Chesapeake Bay (Van Valkenburg \& Flemer 1974, Seliger et al. 1982, Sellner \& Kachur 1987, Baldwin \& Newell 1991, Gallegos 1992).

Except for the $<1 \mu \mathrm{m}$ fraction, flow cytometer counts of autofluorescent particles agreed reasonably well with counts of autotrophs determined by epifluorescence microscopy (Table 2). The lack of correspondence in counts for the $<1 \mu \mathrm{m}$ fraction is probably due to the inability of the flow cytometer to adequately excite and detect these small cells. Other flow cytometer studies examining picophytoplankton typically use lasers with higher power than that used in this study (e.g. Olson et al. 1990, Vaulot et al. 1990).

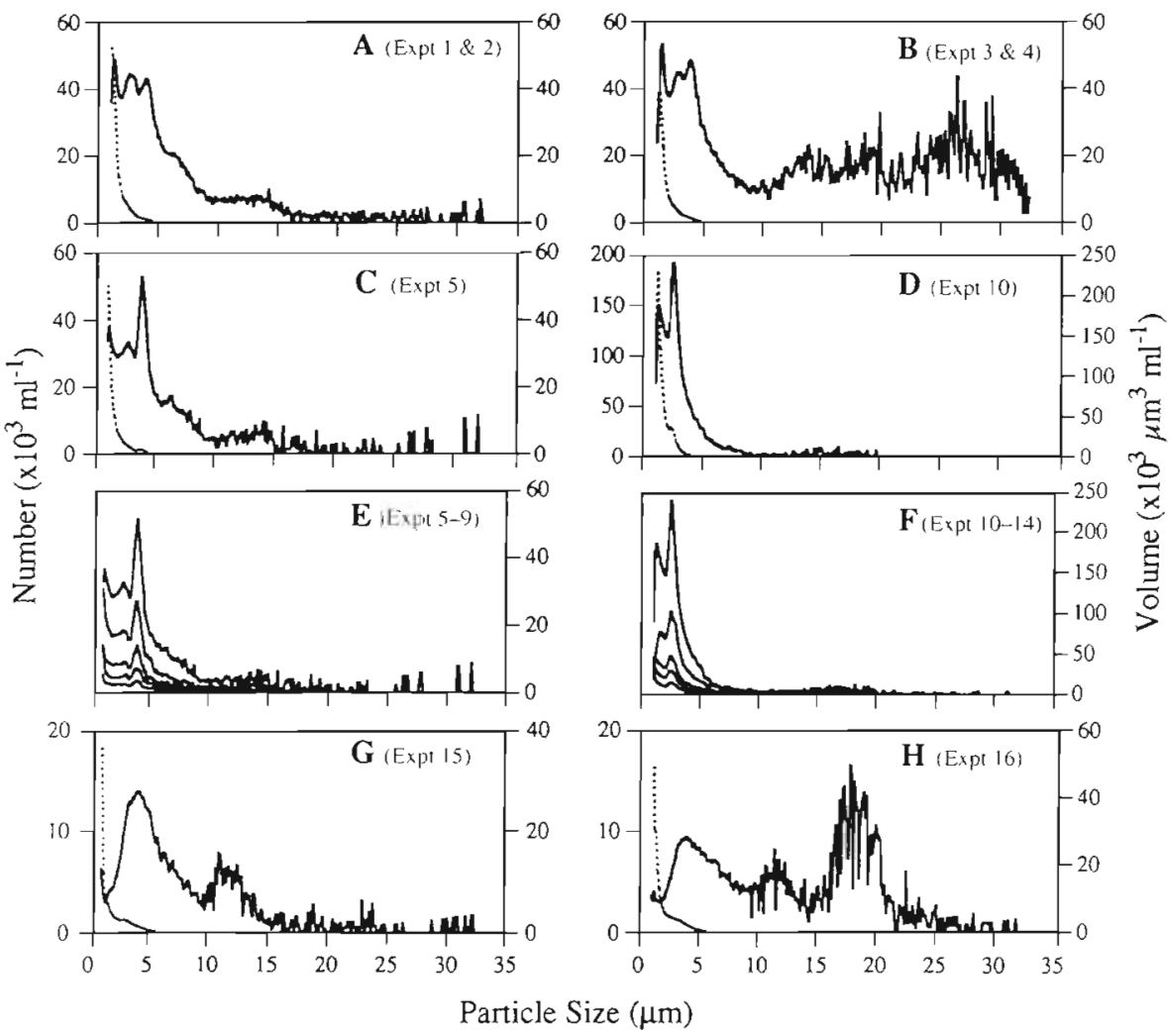

Fig. 1. Size frequency distributions of particle number (dashed lines) and volume (solid lines) for particle suspensions used in feeding experiments with Crassostrea virginica larvae. Experiment numbers correspond to those listed in Table 1 Number distributions not shown for $E$ and $F$. Volume distributions shown in $E$ and $F$ represent percentage dilution of ambient suspensions with filtered river water and are shown in the following order from top to bottom: $0,50,80$, 90 , and $95 \%$. Note differences in scale of $y$-axis among panels 
Table 2. Comparison of mean $(n=2)$ particle counts (particles $\mathrm{ml}^{-1}$ ) determined for a natural sample (Choptank River, Expts 3 and 4) with the Multisizer (M), flow cytometer (FCM), and epifluorescence microscopy. Variance ( \pm 1 SD) listed in parentheses below means. TC/M (\%) represents the percentage of particles counted by the Multisizer that were plankton cells. Mean dinoflagellate abundance; nd: not determined

\begin{tabular}{|c|c|c|c|c|c|c|}
\hline \multirow{2}{*}{$\begin{array}{l}\text { Size fraction } \\
(\mu \mathrm{m})\end{array}$} & \multirow[t]{2}{*}{$\mathrm{M}$} & \multirow[t]{2}{*}{ FCM } & \multicolumn{2}{|c|}{ Microscope counts } & \multirow{2}{*}{$\begin{array}{l}\text { Total cells } \\
\text { (TC) }\end{array}$} & \multirow{2}{*}{$\begin{array}{c}\text { TC/M } \\
(\%)\end{array}$} \\
\hline & & & Autotrophs & Heterotrophs & & \\
\hline $0.5-1$ & nd & $\begin{array}{c}29742 \\
(1503)\end{array}$ & $\begin{array}{c}89105 \\
(11896)\end{array}$ & $\begin{array}{r}4204511 \\
\quad(51854)\end{array}$ & 4293616 & nd \\
\hline $1-3$ & $\begin{array}{l}505401 \\
(35391)\end{array}$ & $\begin{array}{l}54865 \\
(2731)\end{array}$ & $\begin{array}{c}72890 \\
(10766)\end{array}$ & $\begin{array}{l}379077 \\
(53491)\end{array}$ & 451967 & 89 \\
\hline $3-10$ & $\begin{array}{l}45396 \\
(4338)\end{array}$ & $\begin{array}{l}24491 \\
(1307)\end{array}$ & $\begin{array}{l}19021 \\
(2771)\end{array}$ & $\begin{array}{l}5817 \\
(813)\end{array}$ & 24838 & 55 \\
\hline $10-20$ & $\begin{array}{c}1511 \\
(114)\end{array}$ & $\begin{array}{r}1506 \\
(93)\end{array}$ & $\begin{array}{c}1112 \\
(159) \\
803^{\circ}\end{array}$ & $\begin{array}{l}108 \\
(18)\end{array}$ & 1220 & 81 \\
\hline $20-30$ & $\begin{array}{l}736 \\
(60)\end{array}$ & nd & $\begin{array}{c}529 \\
(82) \\
512^{\circ}\end{array}$ & $\begin{array}{l}19 \\
(4)\end{array}$ & 548 & 74 \\
\hline $1-30$ & 553044 & & & & 478573 & 87 \\
\hline
\end{tabular}

The assemblage sampled from the Little Choptank River on June 6, 1992 showed an unusual and moderate volume peak around $12 \mu \mathrm{m}$ but little material larger than $15 \mu \mathrm{m}$ (Fig. 1G). Addition of the dinoflagellate Glenodinium sp. to this assemblage created a large artificial bloom between 15 and $20 \mu \mathrm{m}$ (Fig. 1H) and yielded a final concentration of about 800 cells $\mathrm{ml}^{-1}$ which is within the range of bloom population levels reported for Chesapeake Bay estuaries (Van Valkenburg \& Flemer 1974, Seliger et al. 1982, Sellner \& Kachur 1987, Baldwin \& Newell 1991, Gallegos 1992).

The difference in overall particle density, but the similarity in the size structure of the Choptank and Little Choptank River suspensions collected on August 16, 1991 (Fig. 1C, D), was also reflected in terms of phytoplankton biomass. The biomass of chl a between 0.7 and $30 \mu \mathrm{m}$ in the Little Choptank River $\left(22.30 \mu \mathrm{g} \mathrm{l}^{-1}\right)$ was about twice that in the Choptank River $(11.02 \mu \mathrm{gg}$

Table 3. Mean ( $n=2$ ) chlorophyll a concentrations in suspensions collected from the Choptank and Little Choptank Rivers and used in Expts 5 and 10. Variance $( \pm 1$ SD) given in parentheses after means. Percentage refers to that portion of the total measured chlorophyll $(0.7$ to $30 \mu \mathrm{m})$ in the indicated size fraction

\begin{tabular}{|c|c|c|c|c|}
\hline \multirow{2}{*}{$\begin{array}{l}\text { Size fraction } \\
\qquad(\mu \mathrm{m})\end{array}$} & \multicolumn{2}{|c|}{ Choptank River } & \multicolumn{2}{|c|}{ Little Choptank River } \\
\hline & $\mu \mathrm{g} \mathrm{l^{-1 }}$ & $\%$ & $\mu \mathrm{gl}^{-1}$ & $\%$ \\
\hline $0.7-3$ & $2.21(0.13)$ & 20.0 & $8.36(0.43)$ & 37.5 \\
\hline $3-10$ & $7.36(0.41)$ & 66.8 & $10.48(0.55)$ & 47.0 \\
\hline $10-20$ & $1.39(0.16)$ & 12.6 & $3.03(0.15)$ & 13.6 \\
\hline $20-30$ & $0.07(0.01)$ & 0.6 & $0.43(0.04)$ & 1.9 \\
\hline $0.7-30$ & 11.02 & 100 & 22.30 & 100 \\
\hline
\end{tabular}

$1^{-1}$ ). In the Choptank River, 20 and $87 \%$ of the chl $a$ between 0.7 and $30 \mu \mathrm{m}$ was found in the 0.7 to $3 \mu \mathrm{m}$ and 0.7 to $10 \mu \mathrm{m}$ size fractions (Table 3 ). Similarly, in the Little Choptank River, $38 \%$ and $85 \%$ of the chl $a$ between 0.7 and $30 \mu \mathrm{m}$ was found in the 0.7 to $3 \mu \mathrm{m}$ and 0.7 to $10 \mu \mathrm{m}$ size fractions.

\section{Size range of ingested particles}

At the end of each feeding experiment there were significantly $(p<0.05)$ lower concentrations of total particles remaining in experimental jars containing Crassostrea virginica larvae than in control jars. Generally there was a 10 to $30 \%$ difference in total counts between experimental and control jars. Significant ingestion of particles $>30 \mu \mathrm{m}$ was never detected, thus larval feeding activity is only reported for $\leq 30 \mu \mathrm{m}$ particles.

We detected significant $(p<0.05)$ ingestion of 1 to $10 \mu \mathrm{m}$ particles in all 16 experiments, 0.5 to $1 \mu \mathrm{m}$ particles (presumably cyanobacteria) in each of the 12 experiments counted using the flow cytometer, and $>10 \mu \mathrm{m}$ particles in 4 of the 16 experiments (Table 4). In the 3 experiments where ingestion of larger particles $(\geq 12 \mu \mathrm{m})$ was detected, there were high abundances of large dinoflagellates in suspensions fed to larvae. Comparing the 2 experiments (Expts 15 and 16) conducted on June 6, 1992, it is evident that larvae increased the size range of particles ingested when large cells were made abundant by the addition of the dinoflagellate Glenodinium sp. (Table 4). In the dilution experiments (Expts 5 to 14) larvae ingested 0.5 to $10 \mu \mathrm{m}$ particles (Table 4) regardless of differences in particle abundance (Fig. 1E, F). Finally, large larvae 
Table 4. Crassostrea virginica. Size range of particles ingested by oyster larvae. Size fractions where significant grazing effects were detected (see text) are designated by ' $x$ ' All smaller size intervals $(1-2,2-4,4-6,6-8,8-10 \mu \mathrm{m})$ within the 1 to $10 \mu \mathrm{m}$ size range were ingested and were thus combined for simplicity. Tests of significance for the 1 to $30 \mu \mathrm{m}$ size range were based on Multisizer counts; those for the 0.5 to $1 \mu \mathrm{m}$ fraction with the flow cytometer. Food assemblages designated as in Table 1. nd: not determıned; "large cell dinoflagellate blooms present. Larval size data taken from Table 1

\begin{tabular}{|c|c|c|c|c|c|c|c|c|c|c|}
\hline \multirow[t]{2}{*}{ Expt } & \multirow{2}{*}{$\begin{array}{c}\text { Food } \\
\text { assemblage }\end{array}$} & \multirow{2}{*}{$\begin{array}{l}\text { Mean larval } \\
\text { size }(\mu \mathrm{m})\end{array}$} & \multicolumn{8}{|c|}{ Size fraction $(\mu \mathrm{m})$} \\
\hline & & & $0.5-1$ & $1-10$ & $10-12$ & $12-14$ & $14-16$ & $16-18$ & $18-20$ & $20-30$ \\
\hline 1 & $\mathrm{CR}$ & 124 & nd & $x$ & & & & & & \\
\hline 2 & CR & 260 & nd & $x$ & $x$ & & & & & \\
\hline 3 & $\cdot \mathrm{CR}$ & 107 & $x$ & $x$ & $x$ & $x$ & $x$ & & & \\
\hline 4 & $\cdot C R$ & 278 & $x$ & $x$ & $x$ & $x$ & $x$ & $x$ & $x$ & $x$ \\
\hline $5-9$ & $C R$ & 203 & $x$ & $x$ & & & & & & \\
\hline $10-14$ & LCR & 203 & $x$ & $x$ & & & & & & \\
\hline 15 & LCR & 221 & nd & $x$ & & & & & & \\
\hline 16 & $L C R+G$ & 221 & nd & $x$ & $x$ & $x$ & $x$ & $x$ & $x$ & \\
\hline
\end{tabular}

ingested larger particles and a wider size range of particles than small larvae (Table 4).

\section{Contribution of ingested particles to larval diet}

Of the total particulate material ingested by larvae (as detected using the Multisizer), the largest percentage by number was obtained from the 1 to $3 \mu \mathrm{m}$ size fraction (Fig. 2). Typically, larvae ingested about $80 \%$ of all consumed particles from this range, irrespective of food assemblage offered or larval size tested. However, in terms of total particle volume ingested, larvae often obtained most material from $>3 \mu \mathrm{m}$ particles. Also, their use of different size fractions varied according to the larval size tested and food assemblage offered. For example, when small and large larvae were offered the same food assemblage in Expts 1 and 2,
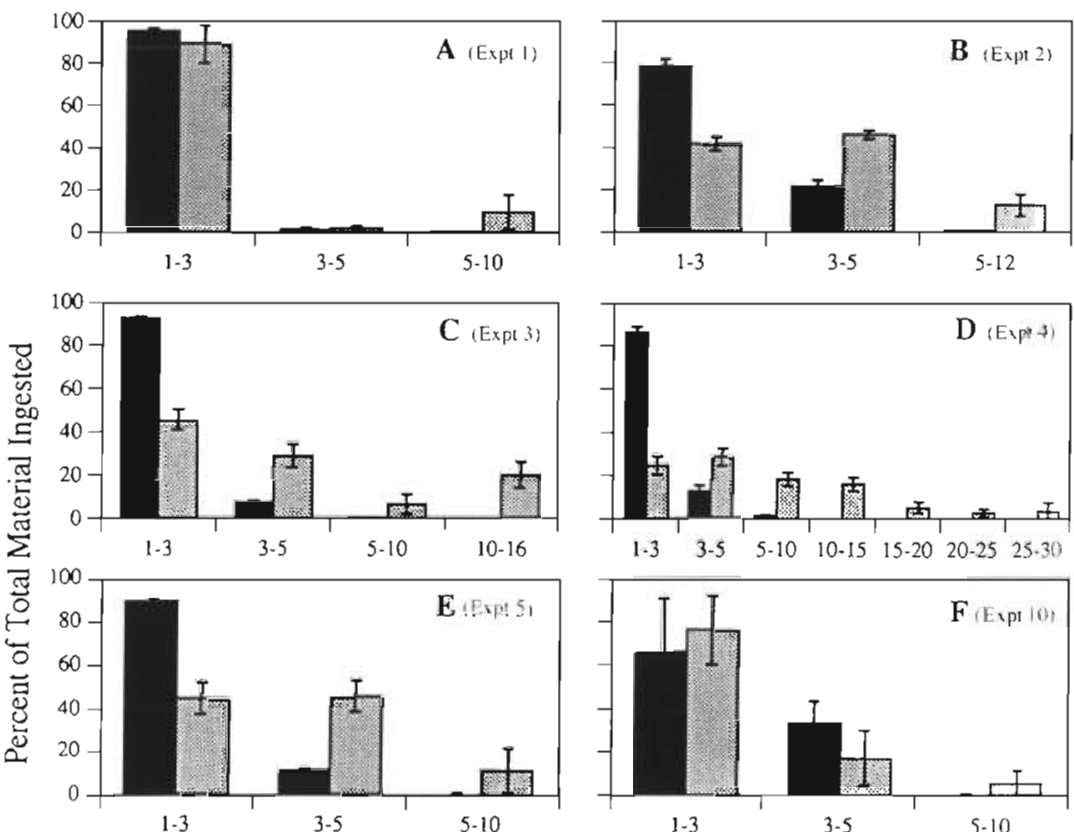

$\begin{array}{llllllll}1-3 & 3-5 & 5-10 & 10-15 & 15-20 & 20-25 & 25-30\end{array}$
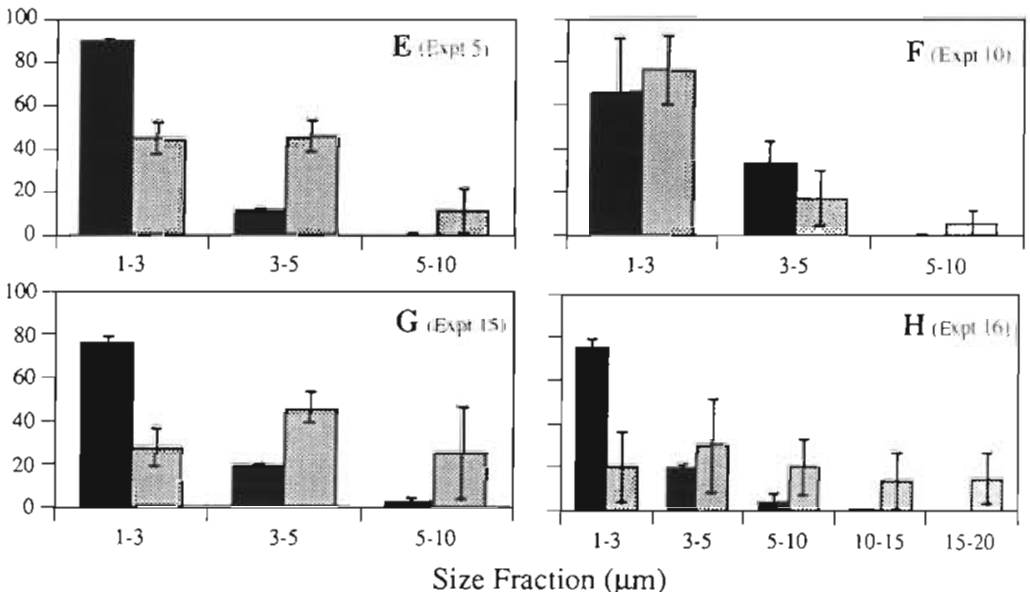

Fig. 2. Crassostrea virginica. Percentage of total particulate material by number and by volume (回) ingested by oyster larvae from different size fractions of natural particle suspensions. Columns are means $(n=5)$, error bars are \pm 1 SD. Experiments correspond to those listed in Table 1. Note differences in scale on the $x$-axis, which indicate the detected size range of particles ingested 
large larvae ingested a slightly wider size range of particles and derived a greater $(\mathrm{p}<0.05)$ percentage (58.7 vs $2.7 \%$ ) of food volume from $>3 \mu \mathrm{m}$ particles than did small larvae (Fig. 2A, B). A similar result occurred in Expts 3 and 4, where an even wider size range of food particles was ingested by both small and large larvae (Fig. 2C, D), apparently due to the abundance of large dinoflagellate cells (Table 2, Fig. 1B). Because large larvae ingested a wider size range of particles than small larvae, these large larvae derived a greater $(p<0.05)$ percentage (75.6 vs $54.9 \%$ ) of food volume from $>3 \mu \mathrm{m}$ particles (Fig. 2C, D). Furthermore, in this dinoflagellate bloom assemblage, small and large larvae obtained 20 and $29 \%$, respectively, of all food volume from $>10 \mu \mathrm{m}$ particles.

Feeding variation due to food assemblage was also apparent for experiments with the same size larvae. For example, in Expts 5 and 10, large larvae ingested a greater $(\mathrm{p}<0.05)$ percentage $(56$ vs $24 \%)$ of total volume from $>3 \mu \mathrm{m}$ particles when offered food from the Choptank River versus the Little Choptank River, even though the same size range of particles was ingested in each assemblage (Fig. 2E, F). In contrast, in Expts 15 and 16, large larvae ingested a similar $(p>0.05)$ percentage ( 79.8 vs $71.9 \%)$ of total volume from $>3 \mu \mathrm{m}$ particles but a wider size range of particles when offered a suspension composed of Little Choptank River particles with added Glenodinium sp. than when offered the Little Choptank River assemblage alone (Fig. 2G, H). In the artificial bloom assemblage containing Glenodinium sp. larvae obtained $29.7 \%$ of all volume from $>10 \mu \mathrm{m}$ particles (Fig. $2 \mathrm{H}$ ).

Finally, in Expts 3, 4, 5, and 10 we detected ingestion of 0.5 to $1 \mu \mathrm{m}$ autofluorescent particles (Table 4). In Table 5 we estimated the contribution of these small particles to overall ingestion in terms of both particle number and volume. Assuming that these autofluorescent particles were near-spherical cyanobacteria with a mean cell diameter of $0.8 \mu$ (diameter based on microscopic observation) and cell volume of $0.268 \mu \mathrm{m}^{3}$, we estimated that these cells can make a significant contribution to the number of particles ingested (up to
$20 \%$ of total ingestion) but a negligible contribution to volume ingested ( $<1 \%$ of total ingestion). However, because the flow cytometer counted only $33 \%$ of $<1$ hm autotrophic cells detected by microscopy (Table 2), the above estimates may be conservative because larvae likely ingested many of the particles that were undetected by the flow cytometer.

\section{DISCUSSION}

\section{Food particle environment}

In general, the size structure of ambient food particle assemblages in summer when Crassostrea virginica larvae are present in Chesapeake Bay is dominated (both by number and volume) by the $<10 \mu \mathrm{m}$ fraction (Fig. 1). This pattern is similar to those reported for other coastal environments (e.g. Poulet 1978, Harbison \& McAlister 1980, Chalermwat 1992) but contrasts with size frequency distributions of neritic, oceanic, and lake waters which typically show volume peaks in the $\geq 10 \mu \mathrm{m}$ range (e.g. Sheldon et al. 1972, Dagg \& Grill 1980, Paffenhöfer et al. 1980, Vanderploeg 1981).

Because the Coulter Multisizer measures particle size based on their equivalent spherical diameter and counts all suspended particles, independent measurements of organic particle abundance are also needed to accurately estimate the size-related availability of food. For example, cells or other particles $>5 \mu \mathrm{m}$ linear dimension may have complex shapes but small volumes and therefore be counted as $<5 \mu \mathrm{m}$ particles. Also, detrital and inorganic particles may represent a large portion of total suspended particles in estuarine environments (Van Valkenburg et al. 1978). However, comparing microscope and Multisizer counts, we found that $87 \%$ of all particles 1 to $30 \mu \mathrm{m}$ in the assemblage used in Expts 3 and 4 were plankton cells as opposed to detritus, etc, and that $94 \%$ of all these cells were 1 to $3 \mu \mathrm{m}$ in maximum dimension (Table 2). Also, most 1 to $3 \mu \mathrm{m}$ cells were spherical or near-spherical. Assuming similar particle assemblage characteristics

Table 5. Crassostrea virginica. Estimated contribution of 0.5 to $1 \mu \mathrm{m}$ particles to the diet of oyster larvae in units of particle number and volume. Particles are assumed to be cyanobacteria of $0.8 \mu \mathrm{m}$ mean diameler and $0.268 \mu \mathrm{m}^{3}$ cell volume. Ingestion of 0.5 to $1 \mu \mathrm{m}$ particles assessed with flow cytometer, 1 to $30 \mu \mathrm{m}$ particles with Multisizer \%: percentage contribution of 0.5 to $1 . \mu \mathrm{m}$ particles to total ingestion $(0.5$ to $30 \mu \mathrm{m})$

\begin{tabular}{|c|c|c|c|c|c|c|c|c|}
\hline \multirow[t]{3}{*}{ Expt } & \multicolumn{8}{|c|}{ Ingestion rate } \\
\hline & \multicolumn{4}{|c|}{ Number (particles larva-1 $\mathrm{n}^{-1}$ ) } & \multicolumn{4}{|c|}{ Volume $\left(\mu \mathrm{m}^{3}\right.$ larva $\left.^{-1} \mathrm{~h}^{-1}\right)$} \\
\hline & $0.5-1 \mu \mathrm{m}$ & $1-30 \mu \mathrm{m}$ & Total & $\%$ & $0.5-1 \mu \mathrm{m}$ & $1-30 \mu \mathrm{m}$ & Total & $\%$ \\
\hline 3 & 587 & 2576 & 3163 & 19 & 157 & 17378 & 17535 & 0.9 \\
\hline 4 & 1421 & 8214 & 9635 & 15 & 381 & 111077 & 111458 & 0.3 \\
\hline 5 & 359 & 12246 & 12605 & 3 & 96 & 93958 & 94054 & 0.1 \\
\hline 10 & 1253 & 9588 & 10841 & 12 & 336 & 99360 & 99696 & 0.3 \\
\hline
\end{tabular}


for all natural suspensions tested in this study, it appears that most particle volume in the $<5 \mu \mathrm{m}$ fraction of the aforementioned size frequency plots represents plankton cells with true linear dimensions of $<5 \mu \mathrm{m}$.

Small plankton cells also dominated phytoplankton biomass (as indicated by chl a concentrations). For example, in the Choptank River (Expt 5) we found that about 20 and $87 \%$ of total chl a 0.7 to $30 \mu \mathrm{m}$ was in 0.7 to 3 and 0.7 to $10 \mu \mathrm{m}$ cells, respectively (Table 3). Similarly, 38 and $85 \%$ of total chl $a$ in the Little Choptank River (Expt 10) was in 0.7 to 3 and 0.7 to $10 \mu \mathrm{m}$ cells, respectively. Together, our data on volume, cell distribution, and phytoplankton biomass illustrate the potential importance of $<10 \mu \mathrm{m}$ particles as food items for oyster larvae in Chesapeake Bay subestuaries.

However, variability in food assemblage size structure is common and occurs over temporal scales that are relevant for oyster larvae, which have a pelagic duration of about 2 to 3 wk (Nelson 1931, Davis \& Guillard 1958). For example, a bloom of $>10 \mu \mathrm{m}$ dinoflagellates (predominantly Gyrodinium uncatenum and Gymnodinium sanguinium) was present at the Choptank River site (Fig. 1B) 5 d after a more typical, low $>10 \mu \mathrm{m}$ distribution was measured there (Fig. 1A). Temporal variability in parficle suspensions is also apparent in the differences among 3 Choptank River samples taken in August 1991 (Fig. 1A to C) and between Little Choptank River samples taken in August 1991 (Fig. 1D) and June 1992 (Fig. 1G). Temporal variability in the abundance and species composition of plankton communities appears to be a general feature of coastal marine environments (Van Valkenburg et al. 1978 , Litaker et al. 1987, Marrasé et al. 1989). Variability in the quantity of suspended material has been reported for other subestuaries of Chesapeake Bay and is thought to affect the growth of adult oysters at these sites (Berg \& Newell 1986). These factors may similarly affect larval growth at such sites (Baldwin \& Newell 1995).

\section{Size range of ingested particles}

In the 16 feeding experiments conducted, we detected ingestion of $\leq 12 \mu \mathrm{m}$ particles in all but the 3 experiments that involved large particle 'bloom' assemblages. Our results indicate that oyster larvae of all sizes typically exploit the relatively narrow particle size range that contains the bulk of available food. Fritz et al. (1984) also found that Crassostrea virginica larvae $(\leq 157 \mu \mathrm{m})$ mainly ingested $<10 \mu \mathrm{m}$ phytoplankton cells collected from Delaware Bay, USA.
However, in the present study it is clear that both small and large larvae can ingest $>12 \mu \mathrm{m}$ particles when this food material is abundant (Table 4). Large larvae appear capable of ingesting particles as large as 28 to $30 \mu \mathrm{m}$ on occasion. This agrees with our previous findings of ingestion of $27 \mu \mathrm{m}$ diameter microspheres and 20 to $30 \mu \mathrm{m}$ cells from natural plankton assemblages (Baldwin \& Newell 1991). This finding also corroborates other studies on Crassostrea virginica larvae reporting ingestion of cultured algae as large as $27 \mu \mathrm{m}$ (Guillard 1958) and ingestion of Delaware Bay phytoplankton as large as $30 \mu \mathrm{m}$ (Mackie 1969).

Our results also demonstrate that larvae can expand the size range of ingested particles as their body size increases (Table 4). Guillard (1958) also found that oyster larvae could ingest larger algal cells as larvae grew, with small $(\leq 100 \mu \mathrm{m})$ larvae ingesting cells up to $12 \mu \mathrm{m}$ and larger (size not stated) larvae ingesting cells as large as $27 \mu \mathrm{m}$. Similarly, Mackie (1969) reported that straight-hinge oyster larvae (presumably $\leq 100 \mu \mathrm{m}$ ) ingested cells about 1 to $10 \mu \mathrm{m}$, and eyed larvae (presumably $\geq 250 \mu \mathrm{m}$ ) expanded this range up to $30 \mu \mathrm{m}$. Expansion of the size range of ingested particles with increasing body size and developmental stage has also been documented for gastropod veligers (Hansen 1991), barnacle nauplii (Stone 1988), and copepods (Poulet 1977. Berggreen et al. 1988, Zankai 1991). Such an ontogenetic change in the size range of ingestible particles may confer advantages to large larvae since, theoretically, they can exploit more potential foods than small larvae. However, it remains to be shown whether a larger 'menu', in conjunction with greater clearance rates (Strathmann 1987, Gallager 1988, Ayukai 1994), merely allows larval energy intake to scale isometrically with metabolic requirements (McEdward 1984), or actually enhances the scope for growth of large larvae.

Finally, because these larvae feed actively on picoplankton (cells 0.5 to $3 \mu \mathrm{m}$ ) and the $\leq 10 \mu \mathrm{m}$ fraction of the nanoplankton (cells 3 to $20 \mu \mathrm{m}$ ), these meroplanktonic grazers may play an ecological role similar to ciliates, linking the production of $\leq 10 \mu \mathrm{m}$ cells to higher trophic levels (Stoecker \& Capuzzo 1990, Gifford 1991.). However, by feeding on small cells similar to those consumed by actively grazing populations of protozooplankton (e.g. Gifford 1991, Bernard \& Rassoulzadegan 1993), oyster larvae may directly compete with them for food resources. On the other hand, this feeding strategy likely reduces their competition with copepods, the dominant metazoan grazer in Chesapeake Bay (White \& Roman 1992), whose diet consists mainly of $\geq 7 \mu \mathrm{m}$ particles (Allan et al. 1977, Richman et al. 1977, Berggreen et al. 1988). 


\section{Relative importance of different particle size fractions to larval diet}

Our study suggests that Crassostrea virginica larvae may derive significant nutritional benefit from food particles outside the size range of cells traditionally considered to support their growth and development. Previous laboratory work on larval growth and feeding emphasized the importance of cells about 3 to $5 \mu \mathrm{m}$ (Walne 1965, Riisgård et al. 1980, Webb \& Chu 1982, Bayne 1983, Sprung 1984, Strathmann 1987, Riisgård 1988). However, we found that $C$. virginica larvae ingested significant amounts of food material $<3$ and $>5 \mu \mathrm{m}$ when presented with more complex natural particle suspensions.

For example, despite being retained at lower efficiencies than larger cells (Baldwin 1995), abundant 1 to $3 \mu \mathrm{m}$ particles (e.g. Table 2) comprise about $80 \%$ of particle numbers and about 20 to $90 \%$ of the particle volume ingested by larvae (Fig. 2). This compares to a volume contribution of about 2 to $40 \%$ for 3 to $5 \mu \mathrm{m}$ particles, 5 to $20 \%$ for 5 to $10 \mu \mathrm{m}$ particles, and 20 to $30 \%$ for 10 to $30 \mu \mathrm{m}$ particles. Because the majority of 1 to $3 \mu \mathrm{m}$ particles in the present study were plankton cells this suggests that picoplankton assemblages are an important food source for oyster larvae. Natural picoplankton has been shown to support significant levels of growth in other molluscan larvae such as gastropods (Bell 1993).

The 1 to 3 m food source may be more important for small larvae than for large larvae. For example, when larvae were fed the same particle assemblage in Expts 1 and 2, small larvae ingested $89 \%$ of all food volume from 1 to $3 \mu \mathrm{m}$ particles whereas large larvae derived only $41 \%$ of all their ingested food from these particles (Fig. 2A, B). Similarly, in Expts 3 \& 4 small larvae ingested $44 \%$ and large larvae ingested $25 \%$ of all food volume from these small particles (Fig. 2C, D). Gallager (1988) also reported that small (100 $\mu \mathrm{m})$ Mercenaria mercenaria larvae ingested a greater mean proportion of small (about $1 \mu \mathrm{m})$ versus large $(4.5 \mu \mathrm{m})$ cells $(48: 1)$ than did large $(234 \mu \mathrm{m})$ larvae $(3: 1)$.

Even smaller $(0.5$ to $1 \mu \mathrm{m})$ picophytoplankton cells are consumed by larvae but these cells contribute $<1 \%$ of the particle volume ingested by larvae (Table 5). However, as previously discussed, we have probably underestimated the ingestion of these small picophytoplankton due to the inability of the flow cytometer to detect all picophytoplankton cells and, perhaps, due to inadequate controls to account for cell growth stimulated by larval nitrogen excretion (see Roman \& Rublee 1980). Also, by including estimates of larval ingestion of $<1 \mu \mathrm{m}$ heterotrophic bacterioplankton into these calculations (not a goal of this study) the actual contribution of all $<1 \mu \mathrm{m}$ picoplankton could be greater still. Crassostrea virginica larvae can ingest $<1 \mu \mathrm{m}$ bacterioplankton but clearance rates for such small particles are low $\left(0.0016 \mathrm{ml} \mathrm{larva}^{-1} \mathrm{~h}^{-1}\right.$; Baldwin \& Newell 1991). However, in carefully controlled laboratory experiments, Douillet (1993b) estimated that cultured bacteria $<1 \mu \mathrm{m}$, when offered as a sole food source at high concentrations $\left(1.5 \times 10^{7}\right.$ cells $\left.\mathrm{ml}^{-1}\right)$, could contribute about $150 \%$ of the carbon requirements of small (about $100 \mu \mathrm{m}$ ) Crassostrea gigas larvae. In similar experiments, Chalermwat (1992) estimated that cultured bacteria could contribute 31,57 , and $13 \%$ of the carbon, nitrogen, and energy requirements, respectively, of small (about $70 \mu \mathrm{m}$ ) Mulinia lateralis larvae. Studies on other larvae of benthic invertebrates indicate that $\leq 1 \mu \mathrm{m}$ cells are ingested and potentially important in their diet (Rivkin et al. 1986, Gallager 1988, Pearse et al. 1991, Ayukai 1994, Gallager et al. 1994) but natural bacterioplankton has only been shown to support significant levels of growth for Antarctic echinoderm larvae (Bosch et al. 1990).

For natural populations of adult bivalves, several studies have estimated that free-living heterotrophic bacteria support $<10 \%$ of the carbon requirements of these animals (Lucas et al. 1987, Crosby et al. 1990 , Langdon \& Newell 1990). Similarly, our results, while based on ingested rather than assimilated material, suggest that $<1 \mu \mathrm{m}$ cells contribute a small percentage of the total food material ingested by small or large larvae when fed a full range of natural $<30 \mu \mathrm{m}$ particles (Table 5). Hence, we predict that the contribution of such small bacteria to larval diets in nature may rest more in terms of essential nutrients (Phillips 1984) than in bulk carbon, nitrogen or energy. Such a supplementary role in larval nutrition is suggested by the work of Douillet \& Langdon (1993) who found that inclusion of cultured bacteria in algal diets enhanced the survival and growth of Crassostrea gigas larvae. Even smaller particles such as viruses and 'colloidal DOM' may also play such a role in larval diets, as is thought for other suspension feeders (Shimeta 1993, Tranvik et al. 1993).

Large particles (10 to $30 \mu \mathrm{m}$ ) were also found to be potentially important in larval diets. On the few occasions when these particles were abundant, such as during dinoflagellate blooms, oyster larvae exploited these particles and derived a significant portion of ingested particle volume from them. For example, in Expts 3, 4, and 16 these particles comprised 20,29 , and $30 \%$ of the total volume ingested by larvae, respectively. In an earlier study on Crassostrea virginica larvae, using a different plankton assemblage and method to measure ingestion, we also found large $(20$ to $30 \mu \mathrm{m})$ cells (presumably blooming dinoflagellates) to constitute an important part of their natural diet (Baldwin \& Newell 1991). Clearly, more work is needed to clarify the types of large particles ingested during bloom conditions, the biochemical 
composition of these particles, and the resultant nutritional benefit to oyster larvae. As indicated by our present and past (Baldwin \& Newell 1991) results, blooms of large cells in Chesapeake Bay may, on occasion, be an important component of the diet of natural populations of bivalve larvae.

Acknowledgements. We thank M. Roman, D. Stoecker, V Kennedy, C. J. Langdon, and 2 anonymous reviewers for their critical reviews of this manuscript. We are also grateful to K. Austin for field and laboratory assistance, to D. Meritt for supplying oyster larvae, and to A. Lewitus for providing algal cultures. This study was supported by Grant \#NA86AAD-SG006 from the National Sea Grant Program, NOAA, to R.I.E.N. and T Jones (University of Maryland), and fellowships from the Horn Point Environmental Laboratory and the Knapp Foundation.

\section{LITERATURE CITED}

Affronti, L. F. JT, Marshall, H. G. (1993). Diel abundance and productivity patterns of autotrophic picoplankton in the lower Chesapeake Bay. J. Plankton Res. 15: 1-8

Allan, J. D., Richman, S., Heinle, D. R., Huff, R. (1977). Grazing in juvenile stages of some estuarine calanoid copepods. Mar. Biol. 43: 317-331

Ayukai, T. (1994). Ingestion of ultraplankton by the planktonic larvae of the crown-of-thorns startish, Acanthaster planci. Biol. Bull. 186: 90-100

Baldwin, B. S. (1992). The natural diet and feeding behavior of planktotrophic larvae of the eastern oyster Crassostrea virginica (Gmelin). Doctoral dissertation, University of Maryland, College Park

Baldwin, B. S. (1995). Selective particle ingestion by oyster larvae (Crassostrea virginica) feeding on natural seston and cultured algae. Mar. Biol. (in press)

Baldwin, B. S., Newell, R. I. E. (1991). Omnivorous feeding by planktotrophic larvae of the eastern oyster Crassostrea virginica. Mar. Ecol. Prog. Ser. 78: 285-301

Baldwin, B. S., Newell, R. I. E. (1995). Functional ingestion response of oyster larvae (Crassostrea virginica) to natural seston and cultured algae. J. exp. mar. Biol. Ecol. (in press)

Bayne, B. L. (1983). The physiological ecology of marine molluscan larvae. In: Verdonk, N. H, van den Biggelaar, J. A. M., Tompa, A. (eds.) The Mollusca, Vol. III, Development. Academic Press, New York, p. 229-343

Bell, J. L. (1993). Feeding and growth of prosobranch veligers Doctoral dissertation. University of Hawaii, Honolulu

Berg, J. A., Newell, R. I. E. (1986). Temporal and spatial variations in the composition of seston avajlable to the suspension feeder Crassostrea virginica. Estuar coast. Shelf Sci. 23: 375-386

Berggreen, U., Hansen, B., Kiørboe, T (1988). Food size spectra, ingestion and growth of the copepod Acartia tonsa during development: implications for determination of copepod production. Mar. Biol. 99: 341-352

Bernard, C., Rassoulzadegan, F. (1993). The role of picoplankton (cyanobacteria and plastidıc picoflagellates) in the diet of tintinnids. J. Plankton Res. 15: 361-373

Bosch, I., Pearse, J. S., Basch, L. V. (1990). Particulate food and growth of planktotrophic sea star larvae in McMurdo Sound, Antarctica. Antarct. J. U.S. 25: 210-212

Chalermwat, K. (1992). Utilization of marine bacteria as a food source by Mulinia lateralis (Say) (Bivalvia: Mac- tridae). Doctoral dissertation, Rutgers University, New Brunswick

Crosby, M. P., Newell, R. 1. E., Langdon, C. J. (1990). Bactenal mediation in the utilization of carbon and nitrogen from detrital complexes by Crassostrea virginica. Limnol. Oceanogr. 35: 625-639

Dagg, M J., Grill, D. W. (1980). Natural feeding rates of Centropages typicus females in the New York Bight. Limnol. Oceanogr. 25: 597-609

Davis, H. C., Guillard, R. R. (1958). Relative value of ten genera of micro-organisms as food for oyster and clam larvae. Fish. Bull. 58: 293-304

Douillet, P. A. (1993a). Bacterivory in Pacific oyster Crassostrea gigas larvae. Mar. Ecol. Prog. Ser. 98: 123-134

Douillet, P. A. (1993b). Carbon contribution through bacterivory in the larvae of the Pacific oyster Crassostrea gigas. Mar. Ecol. Prog. Ser. 102: 303-314

Douillet, P. A., Langdon, C. J. (1993). Effects of marine bacteria on the culture of axenic oyster Crassostrea gigas (Thunberg) larvae. Biol. Bull. 184: 36-51

Fritz, L. W., Lutz, R. A., Foote, M. A., Van Dover, C. L., Ewart, J. W. (1984). Selective feeding and grazing rates of oyster (Crassostrea virginica) larvae on natural phytoplankton assemblages. Estuaries 7: 513-518

Gallager, S. M. (1988). Visual observations of particle manipulation during feeding in larvae of a bivalve mollusc. Bull mar. Sci. 43: 344-365

Gallager, S. M., Waterbury, J. B., Stoecker, D. K. (1994). Efficient grazing and utilization of the marine cyanobacterium Synechococcus sp. by larvae of the bivalve Mercenaria mercenaria. Mar. Biol. 119: 251-259

Gallegos, C. L. (1992). Phytoplankton photosynthesis, productivity, and species composition in a eutrophic estuary: comparison of bloom and non-bloom assemblages. Mar Ecol Prog. Ser. 81: 257-267

Gifford, D. J. (1991). The protozoan-metazoan trophic link in pelagic ecosystems. J. Protozool. 38: 81-86

Guillard, R. R. L. (1958). Some factors in the use of nanoplankton cultures as food for larval and juvenile bivalves. Proc. natl Shellfish. Ass. 48: 134-142

Guillard, R. R. L. (1975). Culture of phytoplankton for feeding marine invertebrates. In: Smith, W. L., Chanley, M. H. (eds.) Culture of marine invertebrate animals. Plenum Press, New York, p. 29-60

Hansen, B. (1991). Feeding behavior in larvae of the opisthobranch Philine aperta: II. Food size spectra and particle selectivity in relation to larval behavior and morphology of the velar structures. Mar. Biol. 111: 263-270

Harbison, G. R., McAlister, V. L. (1980). Fact and artifact in copepod feeding experiments. Limnol. Oceanogr. 25: $971-981$

Kennedy, V S. (1986). Expected seasonal presence of Crassostrea virginica (Gmelin) larval populations, emphasizing Chesapeake Bay. Am. malacol. Bull. 3: 25-29

Langdon, C. J., Newell, R. I. E. (1990). Utilization of detritus and bacteria as food sources by two bivalve suspensionfeeders, the oyster Crassostrea virginica and the mussel Geukensia demissa. Mar. Ecol. Prog. Ser. 58: 299-310

Litaker, W., Duke, C. S., Kenney, B. E., Ramus, J. (1987). Shortterm environmental variabiluty and phytoplankton abundance in a shallow tidal estuary. Mar. Biol. 96: 115-121

Lorenzen, C. J. (1966). A method for the continuous measurement of un vivo chlorophyll concentration. Deep Sea Res. 13: $223-227$

Lucas, M. I., Newell, R. C., Shumway, S. E., Selderer, L. J., Bally, R. (1987). Particle clearance and yicld in relation to bactenoplankton and suspended particulate availability in 
estuarine and open coast populations of the mussel Mytilus edulis. Mar. Ecol. Prog. Ser. 36: 215-224

Mackie, G. (1969). Quantitative studies of feeding in the ovister Crassostrea virginica. Proc. natl Shellfish. Ass. 59: $6-7$ (abstract)

Malone, T C., Ducklow, H. W. (1990). Microbial biomass in the coastal plume of Chesapeake Bay: phytoplanktonbacterioplankton relationships. Limnol. Oceanogr. 35: $296-312$

Marin, V., Huntley, M. E., Frost, B. (1986). Measuring feeding rates of pelagic herbivores: analysis of experimental design and methods. Mar. Biol. 93: 49-58

Marrasé, C., Duarte, C. M., Vaqué, D. (1989). Succession patterns of phytoplankton blooms: directionality and influence of algal cell size. Mar. Biol. 102: 43-48

McEdward, L. R. (1984). Morphometric and metabolic analysis of the growth and form of an echinopluteus. J. exp. mar. Biol. Ecol. 82: 259-287

Mileikovsky, S. A. (1971). Types of larval development in marine bottom invertebrates, their distribution and ecological significance: a re-evaluation. Mar. Biol. 10: $193-213$

Nelson, T. C. (1931). Summary of oyster investigations in Delaware Bay during 1930. Annual Report of the Department of Biology. N.J. Agricult. Exp. Stn Bull 522: 111-122

Olson, R. J., Chisholm, S. W., Zettler, E. R., Altabet, M. A., Dusenberry, J. A. (1990). Spatial and temporal distributions of prochlorophyte picoplankton in the North Atlantic Ocean. Deep Sea Res. 37A: 1033-1051

Paffenhöfer, G.-A., Deibel, D., Atkinson, L. P., Dunstan, W. M. (1980). The relation of concentration and size distribution of suspended particulate matter to hydrography in Onslow Bay, North Carolina. Deep Sea Res. 27 A: 435-447

Pearse, J. S., Bosch, I., Pearse, V. B., Basch, L. V. (1991). Differences in feeding on algae and bacteria by temperate and antarctic sea star larvae. Antarct. J. U.S. 26: 170-172

Phillips, N. W. (1984). Role of different microbes and substrates as potential suppliers of specific, essential nutrients to marine detritivores. Bull. mar. Sci. 35: 283-298

Porter, K. G., Feig, Y S. (1980). The use of DAPI for identifying and counting aquatic microflora. Limnol. Oceanogr. 25: $943-948$

Poulet, S. A. (1977). Grazing of manne copepod developmental stages on naturally occurring particles. J. Fish. Res. Bd Can. 34: 2381-2387

Poulet, S. A. (1978). Comparison between five coexisting species of marine copepods feeding on naturally occurring particulate matter. Limnol. Oceanogr. 23: 1126-1143

Ray, R. T., Haas, L. W., Sieracki, M. E. (1989). Autotrophic picoplankton dynamics in a Chesapeake Bay sub-estuary. Mar. Ecol. Prog. Ser. 52: 273-285

Richman, S., Heinle, D. R., Huff, R. (1977). Grazing by adult estuarine calanoid copepods of the Chesapeake Bay. Mar. Biol. 42: 69-84

Riisgård, H. U. (1988). Feeding rates in hard clam (Mercenaria mercenaria) veliger larvae as a function of algal (Isochrysis galbana) concentration. J. Shellfish Res. 7: 377-380

Riisgård, H. U., Randlov, A., Kristensen, P. S. (1980). Rates of water processing: oxygen consumption and efficiency of particle retention in veligers and young post-metamorphic Mytilus edulis. Ophelia 19:37-47

Rivkin, R. B., Bosch, I., Pearse, J. S., Lessard, E. J. (1986). Bacterivory: a novel feeding mode for asteroid larvae. Science 223: $1311-1314$

Roman, M. R., Rublee, P. A. (1980). Containment effects in copepod grazing experiments: a plea to end the black box approach. Limnol. Oceanogr. 25: 982-990

SAS (1985). SAS users guide: statıstics, version 5 edition. SAS Institute, Inc., Cary, NC

Seliger, H. H., Boggs, J. A., Rivkin, R. B., Biggley, W H., Aspden, K. R. H. (1982). The transport of oyster larvae in an estuary. Mar Biol. 71: 57-72

Sellner, K. G., Kachur, M. E. (1987). Phytoplankton: relationships between phytoplankton, nutrients, oxygen flux and secondary producers. In: Heck, K. L. Jr (ed.) Ecological studies in the midle reach of Chesapeake Bay. SpringerVerlag, New York, p. 12-37

Sheldon, R. W. Prakash, A., Sutcliffe, W. H. (1972). The size distribution of particles in the ocean. Limnol. Oceanogr. 17: $327-340$

Shimeta, J. (1993). Diffusional encounter of submicrometer particles and small cells by suspension feeders. Limnol. Oceanogr. 38: 456-465

Sprung, M. (1984). Physiological energetics of mussel larvae (Mytilus edulis). Il. Food uptake, Mar. Ecol. Prog. Ser. 17: 295-305

Stoecker, D. K., Capuzzo, J. M. (1990). Predation on Protozoa: its importance to zooplankton. J. Plankton Res. 12: 891-908

Stone, C. J. (1988). Test of sequential feeding regimes for larvae of Elminius modestus Darwin (Cirripedia: Balanomorpha). J. exp. mar. Biol. Ecol. 115: 41-51

Strathmann, R. R. (1987). Larval feeding. In: Giese, A. C., Pearse, J S., Pearse, V. B. (eds.) Reproduction of marine invertebrates, Vol. IX, General aspects: seeking unity in diversity. Blackwell Scientific Publications, Palo Alto, p. $465-550$

Thorson, G. (1950). Reproductive and larval ecology of marine bottom invertebrates. Biol. Rev. 25: 1-45

Tranvik, L. J., Sherr, E. B., Sherr, B. F. (1993). Uptake and utilization of 'colloidal DOM' by heterotrophic flagellates in seawater. Mar. Ecol. Prog. Ser. 92: 301-309

Van Valkenburg, S. D., Flemer, D. A. (1974). The distribution and productivity of nanoplankton in a temperate estuarine area. Estuar. coast. mar. Sci. 2: 311-322

Van Valkenburg, S. D., Jones, J. K., Heinle, D. R. (1978). A comparison by size class and volume of detritus versus phytoplankton in Chesapeake Bay. Estuar. coast. mar. Sci. 6: $569-582$

Vanderploeg, H. A. (1981). Seasonal particle-size selection by Diaptomus sicilis in offshore Lake Michigan. Can. J. Fish. Aquat. Sci. 38: 504-517

Vaulot, D., Partensky, F., Neveux, J., Mantoura, R. F. C., Llewellyn, C. A. (1990). Winter presence of prochlorophytes in surface waters of the northwestern Mediterranean Sea. Limnol. Oceanogr. 35: 1156-1164

Walne, P. R. (1965). Observations on the influence of food supply and temperature on the feeding and growth of the larvae of Ostrea eduls. Fish. Invest., Lond. (Ser. II) 24: $1-45$

Webb, K. L., Chu, F.-L. E. (1982). Phytoplankton as a food source for bivalve larvae. In: Pruder, G. D., Langdon, C., Conklin, D. (eds.) Proceedings of the Second International Conference on Aquaculture Nutrition: Division of Continuing Education, Biochemical and Physiological Approaches to Shellfish Nutrition. Louisiana State University, Baton Rouge, p. 272-291

White, J. R., Roman, M. R. (1992). Seasonal study of grazing by metazoan zooplankton in the mesohaline Chesapeake Bay. Mar. Ecol. Prog. Ser. 86: 251-261

Zankai, N. P. (1991). Feeding of nauplius stages of Eudiaptomus gracilis on mixed plastic beads. J. Plankton Res. 13: $437-453$ 